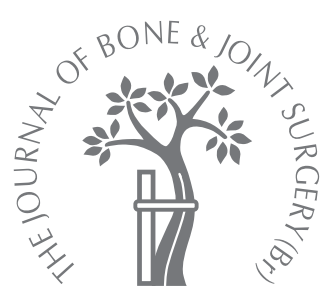

B. George,

A. Abudu,

R. J. Grimer,

S. R. Carter,

R. M. Tillman

From The Royal

Orthopaedic

Hospital NHS

Foundation Trust,

Birmingham,

England

B. George, MRCS

Orthopaedic Oncology

Registrar

A. Abudu, FRCS, Consultant

Orthopaedic Oncology

Surgeon

R. J. Grimer, FRCS

Consultant Orthopaedic

Oncology Surgeon

I. S. R. Carter, FRCS,

Consultant Orthopaedic

Oncology Surgeon

n. M. Tillman, FRCS,

Consultant Orthopaedic

Oncology Surgeon

The Royal Orthopaedic

Hospital, Bristol Road South,

Northfield, Birmingham

B31 2AP, UK.

Correspondence should be sent to $\mathrm{Mr}$ A. Abudu; e-mail:

seggy.abudu@roh.nhs.uk

(C)2008 British Editorial Society of Bone and Joint Surgery doi:10.1302/0301-620X.90B5 $20330 \$ 2.00$

$J$ Bone Joint Surg $[\mathrm{Br}]$

2008;90-B:648-51.

Received 11 October 2007

Accepted 10 January 2008

\title{
The treatment of benign lesions of the proximal femur with non-vascularised autologous fibular strut grafts
}

\begin{abstract}
We report our experience of treating 17 patients with benign lesions of the proximal femur with non-vascularised, autologous fibular strut grafts, without osteosynthesis. The mean age of the patients at presentation was 16.5 years (5 to 33 ) and they were followed up for a mean of 2.9 years $(0.4$ to 19.5$)$. Histological diagnoses included simple bone cyst, fibrous dysplasia, aneurysmal bone cysts and giant cell tumour. Local recurrence occurred in two patients $(11.7 \%)$ and superficial wound infection, chronic hip pain and deep venous thrombosis occurred in three. Pathological fracture did not occur in any patient following the procedure.
\end{abstract}

We conclude that non-vascularised fibular strut grafts are a safe and satisfactory method of treating benign lesions of the proximal femur.

Benign tumours and tumour-like conditions of the proximal femur have a high risk of pathological fracture. Surgical treatment of most benign lesions of the proximal femur includes curettage, bone grafting of the resulting defect and application of a fixation device. Most authors have advocated the use of autologous or allogenic bone grafting and osteosynthesis. ${ }^{1-4}$

We describe our experience of the surgical treatment of benign lesions of the proximal femur using a non-vascularised, autologous fibular strut. The advantage of this technique is that the fibular graft acts as a mechanical strut and as a biological bone graft. No osteosynthesis devices or additional supportive measures are therefore necessary.

\section{Patients and Methods}

All patients who presented to our centre with benign lesions of the proximal femur (Fig. 1) with impending pathological fracture between 1986 and 2006 were included in the study. The database records, case records and radiological findings were reviewed retrospectively.

There were 17 patients, eight males and nine females. Their mean age at the time of presentation was 16.5 years (5 to 33 ) and the mean follow-up was for 2.9 years $(0.4$ to 19.5) (Table I).

The pathological diagnosis was fibrous dysplasia in eight patients $(47 \%)$, simple bone cysts in five $(29.4 \%)$, aneurysmal bone cyst in three $(17.6 \%)$ and giant cell tumour in one $(6.0 \%)$. All patients were assessed preoperatively using radiographs, CT scans and MRI. Patients with characteristic benign lesions such as simple bone cysts or fibrous dysplasia did not undergo pre-operative biopsy and the definitive histological diagnosis was confirmed from tissue obtained at the time of operation. Those with indeterminate or suspicious lesions underwent pre-operative CT-guided or closed needle core biopsy. The indications for surgical treatment were impending pathological fracture, pain, enlarging or apparently aggressive lesions.

Operative technique. The operation is performed under general anaesthesia with the patient either in the lateral or supine position on a radiolucent table. A prophylactic antibiotic, usually Cefuroxime, is given at induction of anaesthesia. The patient is draped from the pelvis to the lower leg with an isolation drape to separate the fibula donor site from the proximal femoral lesion. We try to avoid contamination of the donor site by the pathological lesion. Therefore different gloves and instruments for harvesting the fibula and treatment of the lesion are used. We believe that this reduces the risk of infection and tumour contamination. The upper femur and hip joint are screened under the image intensifier to ensure that the lesion, upper femur and hip joint can be identified both in the anteroposterior and 


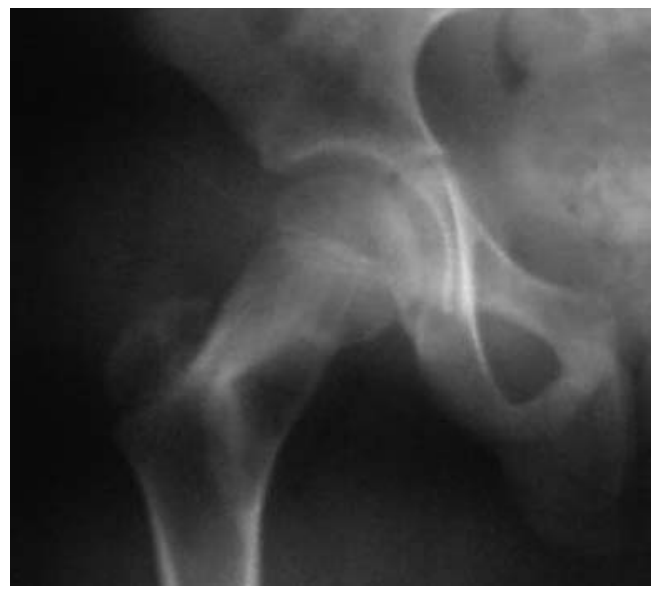

Fig. 1

Radiograph showing a benign lesion in the right femoral neck.

lateral views. The lateral view can often be obtained by external rotation of the hip.

The length of the fibula required is estimated from the MR scan. The fibular graft is harvested first through a lateral skin incision over the mid-shaft of the ipsilateral fibula. The mid-section of the fibula is exposed and the bone dissected sub-periosteally. The estimated length of fibula required plus $2 \mathrm{~cm}$ is excised sub-periosteally. Care is taken that $>5 \mathrm{~cm}$ of the proximal and distal fibula is preserved to ensure stability of the knee and ankle. The periosteum is closed to facilitate fibular reconstitution. The wound is closed in layers and dressed.

A lateral incision is then made from the middle of the greater trochanter as far distally as necessary. The vastus lateralis is elevated anteriorly to expose the femoral shaft. A cortical window is made through the lateral femoral cortex over the femoral lesion under radiological control using a high-speed burr. The window must be large enough to allow adequate curettage of the lesion until underlying normal bone is exposed. A high-speed burr and lavage is used except in young patients with a lesion very close to the unfused physis or where there is significant cortical thinning when a curettage spoon is preferred to avoid damage to the growth plate or the cortex. The harvested fibula is then cut to size and gently hammered into the defect through the cortical window, to fit securely between the proximal and distal normal bone under radiological control. The stability of the impacted fibula is checked by gently pulling on it with a bone hook to ensure that no displacement occurs. No other bone graft or bone substitute is used. The wound is closed. No osteosynthesis or external support is used. Post-operative radiographs are taken (Fig. 2 ) and antibiotic cover given for a further 24 hours. Patients are discharged when they can mobilise toe-touch weight-bearing, usually about 24 to 48 hours after operation. Our patients were followed up at approximately six weeks and three-monthly thereafter with serial radiographs. Progressive increase in weight-bearing was allowed from six weeks after operation and full weight-bearing after three months if the patient felt comfortable and radiographs demonstrated increasing consolidation of the defect.

\section{Results}

All 17 patients full unprotected weight-bearing by a mean of 13.5 weeks (6 to 20 ) after the operation. All returned to normal unrestricted activity 12 months after operation except one treated for a simple bone cyst who developed osteonecrosis of the femoral head. We could not identify the exact cause of the osteonecrosis but this may have been due to the tumour or the surgery.

No patient sustained a pathological fracture of the femur following the procedure. All achieved partial or complete consolidation of the lesion within 12 months. Partial consolidation was defined as more than $50 \%$ radio-opacity of the defect and full consolidation as $100 \%$ radio-opacity.

Complications. There were three post-operative complications; one deep-vein thrombosis which occurred two weeks after surgery in an obese patient, a superficial wound infection which resolved with oral antibiotics and chronic hip pain in the patient with osteonecrosis who required occasional oral analgesia but had no physical limitations. Two patients $(11.7 \%)$ had a recurrence, one with a simple bone cyst and one with fibrous dysplasia. They were managed without further surgery.

We noted partial to complete re-growth of the fibula at the donor site in three patients at a mean of 18 months (12 to 24) after surgery (Fig. 3). Unfortunately not all patients had follow-up radiographs of the donor fibula and an accurate study of fibular regeneration could not be made. The only morbidity at the donor site was in a patient who developed a stress fracture of the re-grown fibula approximately 12 months after operation. This was treated in a plaster cast and healed in four weeks.

\section{Discussion}

The disadvantage of cancellous bone grafting in the treatment of benign proximal femoral lesions is that the graft does not provide structural strength and an additional mechanical device is necessary to prevent fracture. Fixation devices have inherent disadvantages such as an increased risk of infection, tissue irritation, cut out, and in young patients a further operation to remove the device. ${ }^{4}$ Allografts offer the advantage of no donor site morbidity but require the availability of a tissue bank, have a higher risk of infection, a reduced rate of incorporation and a small risk of disease transfer. The advantages of the method used in this study are that the autologous fibula has enough strength without the need for supplementary fixation and promotes biological consolidation.

Our results are similar to those of Enneking and Gearen ${ }^{5}$ who treated 15 patients with fibrous dysplasia with nonvascularised fibular strut grafts without curettage. They 
Table I. Details of the patients

\begin{tabular}{|c|c|c|c|c|c|c|c|}
\hline Age (yrs) & Gender & Indication for surgery ${ }^{*}$ & Diagnosis $^{\dagger}$ & Follow-up (yrs) & Complications $^{\ddagger}$ & Activity $^{\S}$ & $\begin{array}{l}\text { Radiological } \\
\text { appearance }\end{array}$ \\
\hline 9 & $\mathrm{~F}$ & Impending fracture & SBC & 2.8 & $\begin{array}{l}\text { Cyst recurrence managed } \\
\text { conservatively }\end{array}$ & $\begin{array}{l}\text { Normal activity } \\
\text { (FWB } 12 \text { wks) }\end{array}$ & $\begin{array}{l}\text { Partial cyst } \\
\text { consolidation (nine mths) }\end{array}$ \\
\hline 16 & $\mathrm{~F}$ & $\begin{array}{l}\text { Recurrence of cyst } \\
\text { (previous DHS } \\
\text { and grafting) }\end{array}$ & SBC & 2.2 & $\begin{array}{l}\text { Dorsal foot numbness } \\
\text { resolved at six wks }\end{array}$ & $\begin{array}{l}\text { Normal activity } \\
\text { (FWB } 12 \text { wks) }\end{array}$ & $\begin{array}{l}\text { Partial cyst } \\
\text { consolidation ( } 24 \text { mths) } \\
\text { Partial fibula regrowth } \\
\text { ( } 24 \text { mths) }\end{array}$ \\
\hline 5 & $\mathrm{M}$ & Impending fracture & SBC & 1.5 & $\mathrm{Nil}$ & $\begin{array}{l}\text { Normal activity } \\
\text { (FWB } 12 \text { wks) }\end{array}$ & $\begin{array}{l}\text { Almost complete cyst } \\
\text { consolidation at } 18 \mathrm{mths} \\
\text { Partial fibula regrowth } \\
\text { (18 mths) }\end{array}$ \\
\hline 13 & $\mathrm{M}$ & Impending fracture & SBC & 1.3 & $\begin{array}{l}\text { Wound infection settled } \\
\text { with antibiotics } \\
\text { Dorsal foot numbness } \\
\text { settled in } 4 \text { wks }\end{array}$ & $\begin{array}{l}\text { Normal activity } \\
\text { (FWB } 18 \text { wks) }\end{array}$ & $\begin{array}{l}\text { Partial cyst consolidation } \\
\text { at nine mths }\end{array}$ \\
\hline 11 & $\mathrm{M}$ & Expanding tumour & SBC & 0.8 & $\begin{array}{l}\text { Avascular necrosis of } \\
\text { femoral head at } 6 \text { mths }\end{array}$ & $\begin{array}{l}\text { Painful limp, } \\
\text { intermittent use of } \\
\text { walking aids } \\
\text { (FWB } 12 \mathrm{wks} \text { ) }\end{array}$ & $\begin{array}{l}\text { Partial cyst consolidation } \\
\text { (six mths) }\end{array}$ \\
\hline 21 & $\mathrm{~F}$ & Painful deformity & FD & 19.5 & $\begin{array}{l}\text { Recurrence at } 180 \text { mths } \\
\text { managed conservatively } \\
\text { Diagnosed with } \\
\text { Mazabraud's syndrome } \\
\text { with ipsilateral thigh } \\
\text { myxoma excised at } \\
232 \text { mths }\end{array}$ & $\begin{array}{l}\text { Fully mobile } \\
\text { Bisphosphonates for } \\
\text { pain relief successfully } \\
\text { (FWB } 14 \text { wks) }\end{array}$ & $\begin{array}{l}\text { Almost full cyst } \\
\text { consolidation ( } 72 \text { mths) }\end{array}$ \\
\hline 8 & $\mathrm{M}$ & Partial fracture & FD & 2 & Nil & $\begin{array}{l}\text { Normal activity } \\
\text { (FWB } 12 \text { wks) }\end{array}$ & $\begin{array}{l}\text { Partial to full cyst } \\
\text { consolidation (six mths) } \\
\text { Full fibula regrowth } \\
\text { (12 mths) }\end{array}$ \\
\hline 26 & $\mathrm{~F}$ & Impending fracture & FD & 3 & $\begin{array}{l}\text { Dorsal foot numbness } \\
\text { settled } 24 \text { mths } \\
\text { Trochanteric bursitis at } \\
12 \text { mths settled with } \\
\text { steroid injections }\end{array}$ & $\begin{array}{l}\text { Normal activity } \\
\text { (FWB } 12 \text { wks) }\end{array}$ & $\begin{array}{l}\text { Partial to full cyst } \\
\text { consolidation at } 28 \mathrm{mths}\end{array}$ \\
\hline 14 & $\mathrm{~F}$ & Persistent pain & FD & 4 & $\begin{array}{l}\text { Persistent sensation of } \\
\text { ankle instability } \\
\text { Excision tibial Ewing's } \\
\text { sarcoma } 48 \text { mths after } \\
\text { operation }\end{array}$ & $\begin{array}{l}\text { Fully mobile, sarcoma } \\
\text { possible cause of ankle } \\
\text { symptoms } \\
\text { (FWB } 20 \text { wks) }\end{array}$ & $\begin{array}{l}\text { Partial cyst consolidation } \\
\text { (15 mths) }\end{array}$ \\
\hline 9 & $\mathrm{M}$ & Impending fracture & FD & 1.8 & $\begin{array}{l}\text { Slow to return to normal } \\
\text { mobility for social } \\
\text { reasons }\end{array}$ & $\begin{array}{l}\text { Fully weight bearing, } \\
\text { not back to normal } \\
\text { mobility (FWB } 20 \text { wks) }\end{array}$ & $\begin{array}{l}\text { Partial cyst consolidation } \\
\text { (eight mths) }\end{array}$ \\
\hline 12 & $\mathrm{M}$ & Partial fracture & FD & 0.6 & Nil & $\begin{array}{l}\text { Normal activity } \\
\text { (FWB } 12 \text { wks) }\end{array}$ & $\begin{array}{l}\text { Partial cyst consolidation } \\
\text { (seven mths) }\end{array}$ \\
\hline 18 & $\mathrm{~F}$ & Impending fracture & FD & 1.7 & $\mathrm{Nil}$ & $\begin{array}{l}\text { Normal activity } \\
\text { (FWB eight wks) }\end{array}$ & $\begin{array}{l}\text { Partial cyst consolidation } \\
\text { (four mths) }\end{array}$ \\
\hline 16 & $\mathrm{M}$ & Persistent symptoms & FD & 0.4 & $\begin{array}{l}\text { EHL and EDL weakness } \\
\text { settling at six wks }\end{array}$ & $\begin{array}{l}\text { Fully mobile } \\
\text { (FWB six wks) }\end{array}$ & $\begin{array}{l}\text { Partial cyst consolidation } \\
\text { (four mths) }\end{array}$ \\
\hline 26 & $\mathrm{~F}$ & Persistent pain & $A B C$ & 1 & $\begin{array}{l}\text { DVT at four wks treated } \\
\text { medically with } \\
\text { anticoagulants }\end{array}$ & $\begin{array}{l}\text { Normal activity } \\
\text { (FWB } 12 \text { wks) }\end{array}$ & $\begin{array}{l}\text { Partial cyst consolidation } \\
\text { (eight mths) }\end{array}$ \\
\hline 18 & $\mathrm{~F}$ & Partial fracture & $A B C$ & 0.5 & $\mathrm{Nil}$ & $\begin{array}{l}\text { Fully mobile, } \\
\text { awaiting physio for } \\
\text { muscle strengthening } \\
\text { (FWB at } 20 \text { wks) }\end{array}$ & $\begin{array}{l}\text { Partial cyst consolidation } \\
\text { (six mths) }\end{array}$ \\
\hline 25 & $\mathrm{M}$ & Recurrence of cyst & $A B C$ & 0.6 & Nil & FWB 12 wks & Partial cyst consolidation \\
\hline 33 & $\mathrm{~F}$ & $\begin{array}{l}\text { Aggressively } \\
\text { progressive tumour }\end{array}$ & GCT & 4.9 & $\begin{array}{l}\text { Chronic hip pain of } \\
\text { uncertain aetiology, } \\
\text { managed with analgesia }\end{array}$ & $\begin{array}{l}\text { Normal activity } \\
\text { (FWB } 16 \text { wks) }\end{array}$ & $\begin{array}{l}\text { Partial cyst consolidation } \\
\text { (three mths) }\end{array}$ \\
\hline
\end{tabular}

* DHS, dynamic hip screw

† SBC, simple bone cyst; FD, fibrous dysplasia; $A B C$, aneurysmal bone cyst; GCT, giant cell tumour

$\ddagger \mathrm{EHL}$, extensor hallucis longus; EDL, extensor digitorum longus; DVT, deep-vein thrombosis

₹ FWB, full weight bearing

reported a successful outcome in 13 patients. However, two patients required further grafting. All the patients in our series underwent curettage of their lesion as we believe that this is mandatory in patients with giant cell tumours, and is likely to improve long-term local control in patients with tumour-like conditions such as a simple bone cyst. 


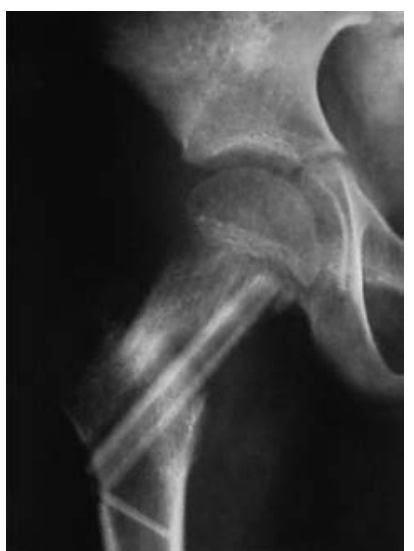

Fig. $2 a$

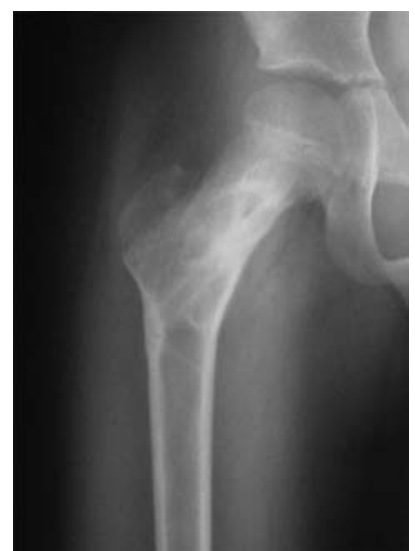

Fig. $2 b$
Radiographs taken a) on the first day after operation, and b) two months post-operatively.

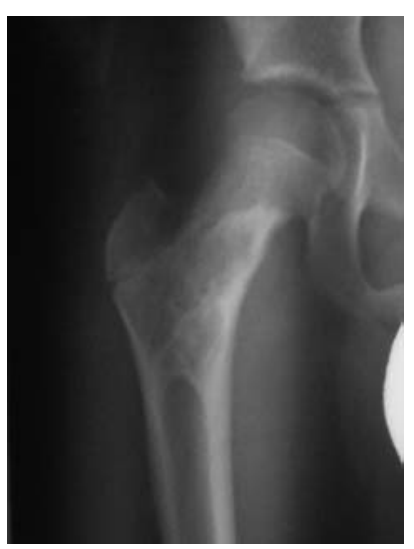

Fig. 3a

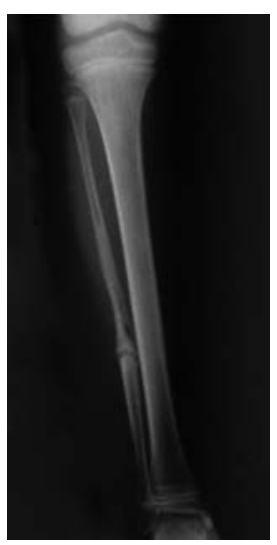

Fig. 3b
Radiographs taken one year after operation showing that the proximal femoral lesion has consolidated and there is evidence of fibular regrowth.

The ideal graft material to use after curettage should be osteoinductive, osteoconductive, osteogenic and easily available. ${ }^{6}$ Autologous cancellous bone graft is rapidly incorporated, easily revascularised and not immunogenic. ${ }^{7}$ It does not provide any immediate structural support, however within six to 12 months it attains strength similar to cortical graft. ${ }^{6,8}$ The main drawbacks of cancellous bone are a failure rate of up to $48 \%$ if used on its own, and limited supply for large defects. ${ }^{5}$ Jaffe and Dunham ${ }^{4}$ reported the use of autologous cancellous bone as an adjunct to fill any remaining defect after treating proximal femoral benign lesions with cortical allografts and a dynamic hip screw.

Autologous non-vascularised cortical grafts provide excellent structural support at their recipient site.6,9 The rich blood supply of the recipient site in the proximal femur is advantageous for the vascularisation of non-vascularised cortical bone grafts. Revascularisation causes reduction in the biomechanical strength of the bone graft in the first few weeks when it is best to restrict patients activities. However, normal strength is regained by six to 12 months, hence our decision to allow full unrestricted activities from 12 months after surgery. ${ }^{4,6,7,9}$

Some authors recommend that osteosynthesis or physical support such as a hip spica are necessary after cortical strut grafts ${ }^{4}$ but our results show that this is not necessary. The reconstruction needs to be protected for about six weeks by keeping the patient non-weight-bearing until there is clear radiological evidence of incorporation between the graft and the lateral femoral cortex. ${ }^{1,9}$

Vascularised autologous cortical bone does not weaken as it does not undergo resorption. It is remodelled in a similar fashion to normal bone and is a superior graft to its nonvascularised counterpart. ${ }^{6,9}$ Vascularised autologous cortical bone was reported by Plakseychuk et al, ${ }^{10}$ to give superior results to its non-vascularised equivalent in the treatment of osteonecrosis of the femoral head. However, despite superior results, the use of vascularised free grafts is called into question by the complexity of the procedure, the increased operating time required and the need for microsurgical techniques.

Allograft incorporation is slower and less complete than an equivalent autograft. The main advantage of allografts is their plentiful supply, versatility, and the lack of any donor site morbidity. ${ }^{6,7}$ The use of bone graft substitutes such as bone cement and biocompatible materials offer the surgeon an alternative choice of graft material, but they do not offer structural support or integrate well with bone. , $^{3,11,12}$

We conclude that non-vascularised fibular strut autografts are a safe and effective method of treating benign lesions of the proximal femur, without the use of osteosynthesis.

No benefits in any form have been received or will be received from a commercial party related directly or indirectly to the subject of this article.

\section{References}

1. Jaffe KA, Launer EP, Scholl BM. Use of a fibular allograft strut in the treatment of benign lesions of the proximal femur. Am J Orthop 2002;31:575-8.

2. Shih HN, Cheng CY, Chen YJ, Huang TJ, Hsu RWW. Treatment of the femoral neck and trochanteric benign lesions. Clin Orthop 1996;328:220-6.

3. Shih HN, Chen YJ, Huang TJ, Hsu KY, Hsu RWW. Treatment of fibrous dysplasia involving the proximal femur. Orthopedics 1998;21:1263-6.

4. Jaffe KA, Dunham WK. Treatment of benign lesions of the femoral head and neck. Clin Orthop 1990;257:134-7.

5. Enneking WF, Gearen PF. Fibrous dysplasia of the femoral neck: treatment by cortical bone grafting. J Bone Joint Surg [Am] 1986;68-A:1415-22.

6. Finkemeier CG. Bone grafting and bone graft substitutes. J Bone Joint Surg [Am] 2002;84-A:454-64.

7. Burchardt H. The biology of bone graft repair. Clin Orthop 1983;174:28-42.

8. Gazdag AR, Lane JM, Glaser D, Forster RA. Alternatives to autogenous bone graft: efficacy and indications. J Am Acad Orthop Surg 1995;3:1-8.

9. Dell PC, Burchardt H, Glowczewski FP Jr. A roentgenographic, biomechanical, and histological evaluation of vascularized and non-vascularized segmental fibular canine autographs. J Bone Joint Surg [Am] 1985;67-A:105-12.

10. Plakseychuk AY, Kim SY, Park BC, et al. Vascularized compared with nonvascularized fibular grafting for the treatment of osteonecrosis of the femoral head. J Bone Joint Surg [Am] 2003;85-A:589-96.

11. Nicholas RW, Lange TA. Granular tricalcium phosphate grafting of cavitary lesions in human bone. Clin Orthop 1994;306:197-203.

12. Ichida A, Araki N, Shinto $\mathbf{Y}$, et al. The use of calcium hydroxyapatite ceramic in bone tumour surgery. J Bone Joint Surg [Br] 1990;72-B:298-302. 